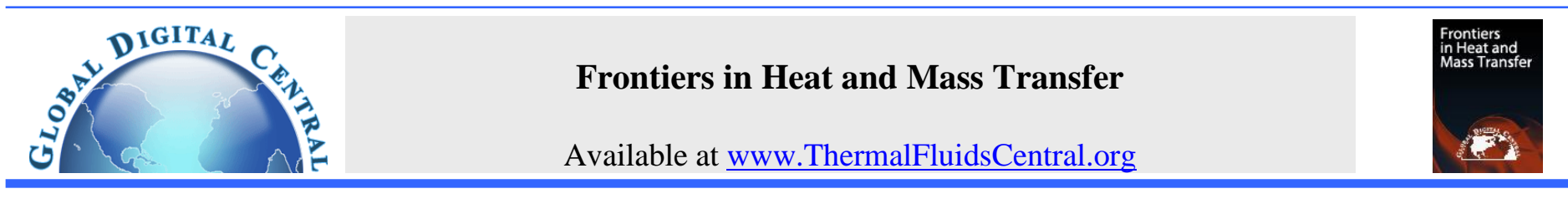

\title{
PROCESS INTEGRATION OF SULFURIC ACID PLANT BASED ON CONTACT PROCESS
}

\author{
Misbahudin Alhanif, Gelbert Jethro Sanyoto, Widayat Widayat* \\ Department of Chemical Engineering, Faculty of Engineering, Diponegoro University, Semarang, Indonesia, 50275
}

\begin{abstract}
Development of sulfuric acid production method has taken us to commercial use of contact process in most industries. However, most plants still utilize coolers and steam generators to divert the excess heat. This method of energy recovery is inefficient, thus, this study attempts to redesign commercial heat exchanger network for better efficiency and lower cost. Process integration using composite curve, cascade diagram, heat exchanger network alternatives, completed with improved plant flow diagram are successfully calculated and analyzed by HINT software. Total energy saving can reach up to $74.70 \%$ and this results in total cost saving up to $\$ 18,000 /$ year.
\end{abstract}

Keywords: Contact process, process integration, sulfuric acid.

\section{INTRODUCTION}

Sulfuric acid $\left(\mathrm{H}_{2} \mathrm{SO}_{4}\right)$, previously known as oil of vitriol, is one of inorganic chemical compounds popular for its highly corrosive property (Panossian et al., 2012). Nevertheless, it is one of the essential chemical compounds throughout the history and actively participates in many kinds of reactions. It can act as raw material used in a wide range of industrial processes (Gominšek et al., 2005 and Kumar et al., 2015) or as catalyst, enabling faster reaction rate (Kobayashi et al., 1960 and Bujang et al., 2013). This leads to high demand of the manufactured sulfuric acid in the production of fertilizers (Górecka et al., 2007), metal leaching industry (Khalid et al., 2019), pigment (dye) production (Tongwen and Weihua, 2001), paper production (M'hamdi et al., 2017), and petroleum refining (Ferdous et al., 2013). Large quantity of sulfuric acid is manufactured on a global scale with the production of the chemical often being linked to the stage of development of a country, on account of the large number of process transformation used throughout the progress (Speight, 2017).

Starting from its first-known production method, the destructive distillation of ferrous sulfate, methods of mass-producing sulfuric acid keep developing until the method we've known as "contact process". Compared to the previous method, the "lead-chamber", contact process is far more economical and uses less expensive catalyst, vanadium oxide $\left(\mathrm{V}_{2} \mathrm{O}_{5}\right)$. Therefore, most sulfuric acid industries nowadays utilize contact process in fulfilling the never-ending demand of sulfuric acid. While the design for each industry may be various, sulfur furnace, multi-pass converter, and absorbing towers are essentials (Kiss et al., 2006).

Given the fact that sulfuric acid conversion is exothermic process, efforts are needed in keeping the temperature at desired degree. While installation of coolers at each pass is proven to be beneficial, it's a waste of potential heat energy, thus, process integration is recommended to be applied to this energy-intensive process. Process integration is similar in principle to exergy analysis. Exergy analysis is carried out to minimize environmental energy loss, while process integration is carried out to utilize the heat dissipated by process equipment for use in other process equipment. Fundamental and practical exergy analysis has been widely studied by previous researchers (Shabgard and Faghri, 2019).

Attempts in process integration of sulfuric acid plant revolve around the installation of economizers (Acton, 2011). While the term economizer comes from the word "to economize", it's the result of energy recovery effort by making use of enthalpy from hot stream to preheat the cold stream to desired temperatures. In contact process, economizers may be installed at the output of a converter prior entering the next pass. However, most plants utilize the excess heat to turn cold feed water into medium pressure steam, which is then used to move power generators (Kemmerich and Storch, 2016). This method of energy recovery is inefficient, since the energy generated is insignificant compared to the energy used to heat up the stream. Therefore, this study further investigates on the possibility of more efficient sulfuric acid process integration, preferably by direct utilization of excess heat in a heat exchanger network. Based on maximum energy recovery and cost targeting, minimum temperature difference of hot and cold streams is assumed to be $10 \mathrm{~K}$. Hopefully, this kind of process integration method may mitigate the need to install power generators and give higher overall energy efficiency.

\section{SULFURIC ACID PLANT DESIGN}

During contact process, manufactured sulfuric acid underwent fourstage process starting from melting the elemental sulfur:

$\mathrm{S}_{(\mathrm{s})} \rightarrow \mathrm{S}_{(\mathrm{l})}$

$\mathrm{S}_{(\mathrm{l})}+\mathrm{O}_{2(\mathrm{~g})} \rightarrow \mathrm{SO}_{2(\mathrm{~g})}$

$2 \mathrm{SO}_{2(\mathrm{~g})}+\mathrm{O}_{2(\mathrm{~g})} \rightarrow 2 \mathrm{SO}_{3}(\mathrm{~g})$

$\mathrm{SO}_{3(\mathrm{~g})}+\mathrm{H}_{2} \mathrm{O}_{(\mathrm{l})} \rightarrow \mathrm{H}_{2} \mathrm{SO}_{4(\mathrm{aq})}$

The initial step, melting of elemental sulfur, is the predominant step of sulfuric acid manufacture, which gives the $S$ element needed in its formula. But, in order to incorporate this single element, it has to be reacted with dry oxygen air to form sulfur dioxide. Since the reaction of 
sulfur with dry air is exothermic, produced sulfur dioxide must be cooled to avoid reaction reversal. It is then fed to a multi-stage catalytic fixed bed reactor (often referred to as the converter) where it is catalytically oxidized to sulfur trioxide. From the first stage until the third, the overall sulfur dioxide conversions are $63 \%, 84 \%$, and $93 \%$ respectively. Keep in mind that each stage requires cooling and it is provided by installing coolers and economizers. Output from the third stage enters the first absorption tower, absorbed using concentrated sulfuric acid (98\%), before than flowed to the fourth, the last stage of sulfur dioxide conversion. At this stage, the overall conversion will reach up to $99.5 \%$ and proceeds to the second absorption tower. Finally, the sulfur trioxide is absorbed in another strong sulfuric acid solution which promotes the reaction of sulfur trioxide with water, producing sulfuric acid. Overall flowsheet of this process can be seen in Fig. 1.

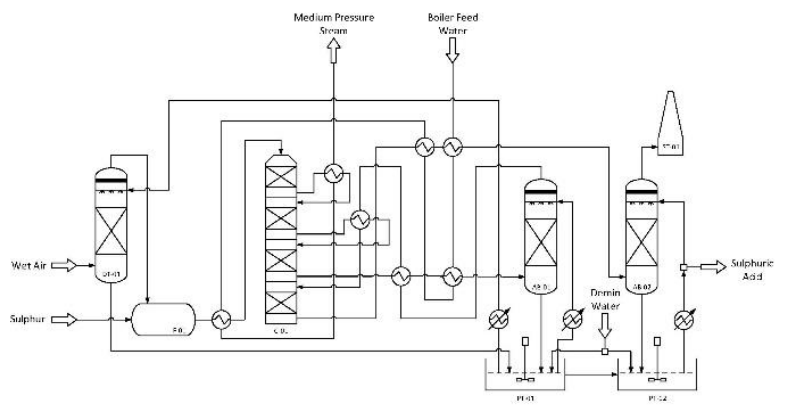

Fig. 1 Flowsheet of sulfuric acid plant

Twelve main streams are present in this process, with eight hot streams and four cold streams. One of the cold streams is cold feed water which will be used in its medium pressure steam form. While the other streams actively participate, the feed water is out of the whole process and merely used to reduce the stream temperature, in other words, it acts a cooler. However, since its flow is connected from one heat exchanger to the other, it's assumed to be one of the main streams in the process.

All of the main process streams with the supply, target temperature, and heat capacity are presented in Table 1 .

Table 1 Sulfuric acid plant main process streams.

\begin{tabular}{|c|l|c|c|c|c|}
\hline $\begin{array}{l}\text { No. of } \\
\text { stream }\end{array}$ & Stream & Type & Ts (K) & Tt (K) & $\begin{array}{c}\text { CP } \\
(\mathrm{MW} / \mathrm{K})\end{array}$ \\
\hline C1 & Dry air input & Cold & 387 & 1296 & 7725.3 \\
\hline C2 & $\begin{array}{l}\text { Molten sulfur } \\
\text { input }\end{array}$ & Cold & 401 & 1296 & 749.7 \\
\hline H1 & $\begin{array}{l}\text { Furnace } \\
\text { output }\end{array}$ & Hot & 1296 & 694 & 7871.8 \\
\hline H2 & $\begin{array}{l}1^{\text {st }} \text { converter } \\
\text { output }\end{array}$ & Hot & 891 & 708 & 160.8 \\
\hline H3 & $\begin{array}{l}2^{\text {nd }} \text { converter } \\
\text { output }\end{array}$ & Hot & 777 & 719 & 158.7 \\
\hline H4 & $\begin{array}{l}3^{\text {rd }} \text { converter } \\
\text { output }\end{array}$ & Hot & 722 & 483 & 7441.8 \\
\hline C3 & $\begin{array}{l}\text { Last converter } \\
\text { input }\end{array}$ & Cold & 347 & 674 & 6396.0 \\
\hline H5 & $\begin{array}{l}\text { Last converter } \\
\text { output }\end{array}$ & Hot & 682 & 483 & 6366.0 \\
\hline H6 & $\begin{array}{l}1^{\text {st }} \text { absorber } \\
\text { input }\end{array}$ & Hot & 355 & 332 & 120158.8 \\
\hline H7 & $\begin{array}{l}2^{\text {nd }} \text { absorber } \\
\text { input }\end{array}$ & Hot & 355 & 332 & 4506.5 \\
\hline H8 & $\begin{array}{l}\text { Sulfuric acid } \\
\text { tank }\end{array}$ & Hot & 355 & 332 & 106727.5 \\
\hline C4 & Feed water & Cold & 377 & 683 & 12935.2 \\
\hline
\end{tabular}

The value and calculations are based on sulfuric acid production capacity at 3,270 tons/week or approximately 170,000 tons/year, the average capacity of sulfuric acid plants. Nevertheless, it still leaves possibility for scaling-up without drastic changes in the main key processes.

Using HINT software, streams, properties, and heat exchanger network of sulfuric acid plants can be presented as shown in Fig. 2. Since the next sections will present alternatives of heat exchanger networks, for better understanding, this design will be called "initial" heat exchanger network.

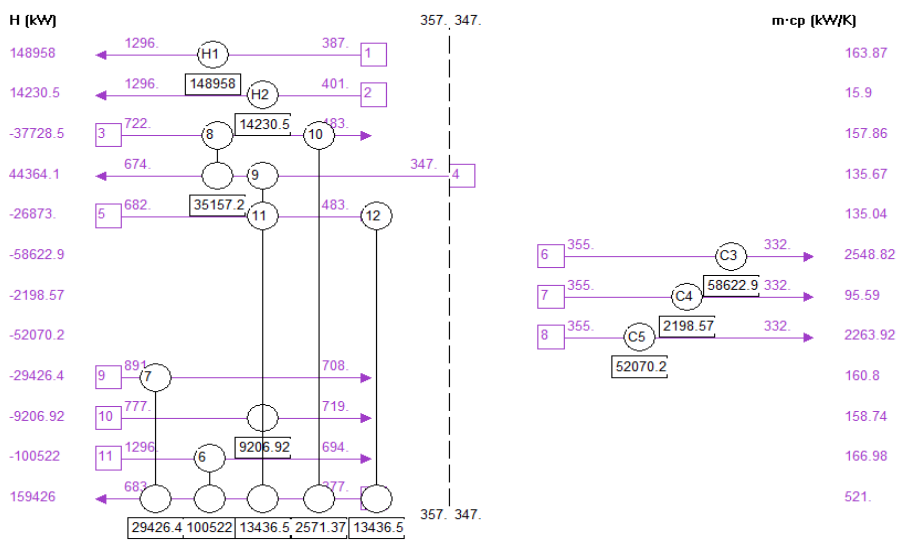

Fig. 2 Flowsheet of sulfuric acid plant

From Fig. 2., it can be seen that the pinch point is at $352 \mathrm{~K}$ with streams passing neither above nor below pinch areas. This limits the installation of utility since above pinch is exclusively for heaters, while below pinch is for coolers. Without any hot stream present in below pinch, only coolers can be used in this case. Fortunately, both kinds of streams are present in above pinch, thus enables the installations of some economizers. Surprisingly, this design is what used commercially, even the heat exchanger network from Fig. 2 is a mere interpretation from sulfuric acid plant flowsheet showed in Fig. 1. Energy recovery from this design is 2,091,451 MW/year with heating and cooling duty required are 7,693,172 MW/year and 12,836,266 MW/year respectively (included feed water).

\section{PROCESS INTEGRATION}

Since the usage of feed water doesn't contribute directly with the reaction, process integration alternatives are designed through reanalyzing new pinch point and reconstruction of new heat exchanger networks (Djaeni et al., 2010 and Sojitra, 2016). The objective is achieved by following the steps for pinch analysis:

- Data extraction: identifying hot and cold streams, properties, supply, and target temperatures, which are same as the initial presented in Table 1 with feed water stream is omitted.

- Cascade/problem table algorithm: configuring temperature intervals and composite curves to determine the maximum energy that can be recovered, minimum hot and cold utility required and pinch point temperature.

- Heat exchanger network design: matching the potential hot and cold streams of the process to reduce usage of external energy, and estimating energy recovery by installing a number of heat exchangers.

Assumptions of this design is that:

- Constant physical properties (density, specific heat).

- $\quad$ Pressure drop is negligible.

- Well-mixed subsystem. 
- At the exit of each unit, all components have the same temperature.

- Minimum temperature difference is $10 \mathrm{~K}$.

- Heaters and coolers used are releasing/absorbing the energy completely.

\section{CASE STUDY}

\subsection{Revamped Sulfuric Acid Plant}

From Table 1, the existing heat exchanger network (HEN) was found to have eight heat flows and four cold flows. Figure 2 shows a grid diagram for an existing HEN. There are total of 12 heat exchangers in the process. This includes seven process-to-process heat exchangers, three coolers $(\mathrm{C})$, and two heaters $(\mathrm{H})$. The total hot and cold utilities used were 7,693,172 MW/year and 12,836,266 MW/year, respectively, including of feed water to produce MP steam used for heating utilities with a total heat recovery of 2,091,451 MW/year.

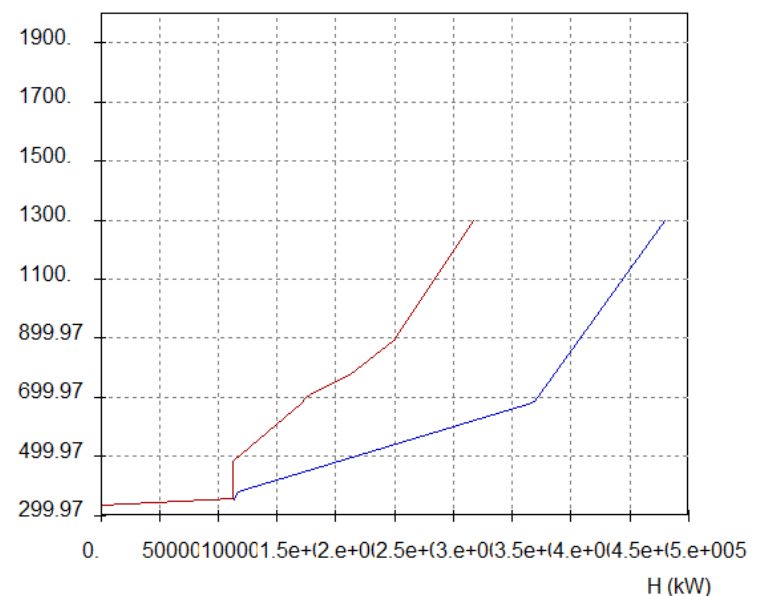

Fig. 3 Composite curve existing plant

Based on the composite curve (see Fig. 3) and the amount of heating and cooling loads on an existing design, an increase in recovery energy has the opportunity to be made through changes in the amount of $\Delta \mathrm{T}_{\min }$ or by revamping an existing design. Putra (2017) found that the change in $\Delta \mathrm{T}_{\min }$, would not significantly affect the heating and cooling duties. Conversely, this will increase plant complexity if $\Delta \mathrm{T}_{\min }$ is made smaller. This is evidenced from the results of a calculation using the HINT software, if $\Delta \mathrm{T}_{\min }$ is changed to $5 \mathrm{~K}$, the recovery energy obtained is $2,128,231 \mathrm{MW} /$ year with a minimum HE of 13 . This means that the amount of recovery energy has only increased by $1.76 \%$ compared to using $\Delta \mathrm{T}_{\min }=10 \mathrm{~K}$. Even this change may not be implemented in the sulfuric acid industry because of its complexity and $\Delta \mathrm{T}_{\min }$ fluid is usually above $10 \mathrm{~K}$.

Based on this analysis, revamping the plant design is possible. Revamping the design can occur due to changes in plant capacity or by changing the use of utility resources (Wang et al., 2011). The revamping design in this case study will be done through the replacement of feed water (stream 12) as a producer of MP steam using another utility source. Therefore, the number of hot and cold streams that can be integrated on the sulfuric acid plant are 8 and 3, respectively (shown in Table 2).

Table 2 Sulfuric acid plant main process streams after improvement.

\begin{tabular}{|c|l|c|c|c|c|}
\hline $\begin{array}{c}\text { No. of } \\
\text { stream }\end{array}$ & Stream & Type & Ts (K) & Tt (K) & $\begin{array}{c}\text { CP } \\
(\mathrm{MW} / \mathrm{K})\end{array}$ \\
\hline C1 & Dry air input & Cold & 387 & 1296 & 7725.3 \\
\hline C2 & $\begin{array}{l}\text { Molten sulfur } \\
\text { input }\end{array}$ & Cold & 401 & 1296 & 749.7 \\
\hline
\end{tabular}

\begin{tabular}{|c|l|c|c|c|c|}
\hline H1 & Furnace output & Hot & 1296 & 694 & 7871.8 \\
\hline H2 & $\begin{array}{l}1^{\text {st }} \text { converter } \\
\text { output }\end{array}$ & Hot & 891 & 708 & 160.8 \\
\hline H3 & $\begin{array}{l}2^{\text {nd }} \text { converter } \\
\text { output }\end{array}$ & Hot & 777 & 719 & 158.7 \\
\hline H4 & $\begin{array}{l}3^{\text {rd }} \text { converter } \\
\text { output }\end{array}$ & Hot & 722 & 483 & 7441.8 \\
\hline C3 & $\begin{array}{l}\text { Last converter } \\
\text { input }\end{array}$ & Cold & 347 & 674 & 6396.0 \\
\hline H5 & $\begin{array}{l}\text { Last converter } \\
\text { output }\end{array}$ & Hot & 682 & 483 & 6366.0 \\
\hline H6 & $\begin{array}{l}1^{\text {st }} \text { absorber } \\
\text { input }\end{array}$ & Hot & 355 & 332 & 120158.8 \\
\hline H7 & $\begin{array}{l}2^{\text {nd }} \text { absorber } \\
\text { input }\end{array}$ & Hot & 355 & 332 & 4506.5 \\
\hline H8 & $\begin{array}{l}\text { Sulfuric acid } \\
\text { tank }\end{array}$ & Hot & 355 & 332 & 106727.5 \\
\hline
\end{tabular}

\subsection{New Composite Curve}

The above analysis has shown what needs to be done to improve the design of the current heat exchanger network. Replacement of feed water as a producer of MP steam is a solution that can be done to significantly improve the design of heat exchanger network. Composite curves for the new design (see Fig. 4) can be made from data in the Table 2 with $\Delta \mathrm{T}_{\min }$ of $10 \mathrm{~K}$. Figure 4 shows that the plant has a maximum heat recovery of 9,455,655 MW/year (352.1\% increase from the initial design) with a minimum HE of 15 . The minimum heating utility ( $\mathrm{QH}_{\mathrm{H} \text { min }}$ ) target is $328,947 \mathrm{MW} /$ year and the minimum cooling utility ( $\mathrm{Q}_{\mathrm{Cmin}}$ ) is $5,472,060$ MW/year.

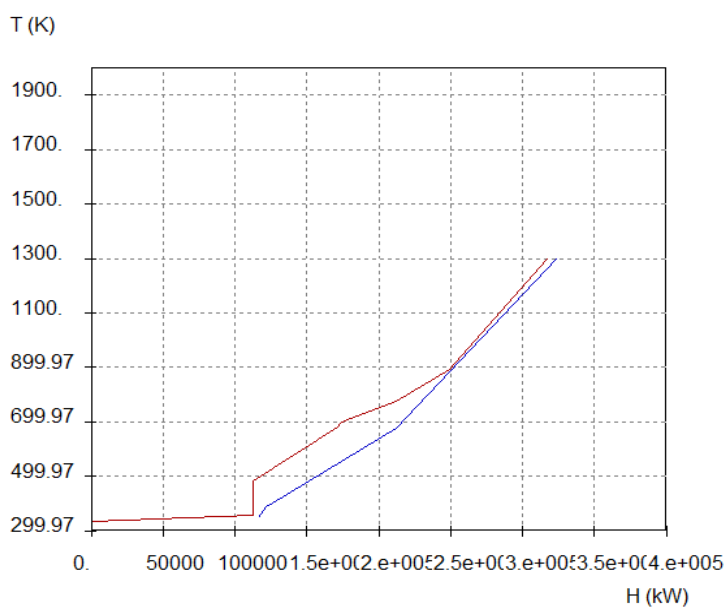

Fig. 4 Composite curve of new plant design

\subsection{Cascade Diagram}

A cascade diagram can be created using the Problem Table or using HINT software. The problem table, developed by Linnhoff and Flower (1978), shows the relevant process streams of data to the energy analysis in an organized table format. These data are used to generate the energy balance to apply Pinch Technology. From the cascade diagram, it can be known that the pinch point is at a temperature of $886 \mathrm{~K}(881 \mathrm{~K}$ for cold stream and $891 \mathrm{~K}$ for hot stream. On this temperature of $304 \mathrm{~K}$ resulting in enthalpy of $0 \mathrm{~kW}$ (see Fig. 5).

\subsection{Alternative Design 1}

Heat Exchanger Networks (HEN) can be made by matching heat and cold streams using HINT software with a maximum energy recovery target. Pinch point value obtained from the cascade diagram at a 
temperature of $886 \mathrm{~K}$. Based on pinch point, it can be known the area of above pinch and below pinch. From the data in Table 2 , it can be matching heat and cold streams, the addition of utilities, and heat exchangers so that the system can be recovering energy as much as possible. Figure 6 shows the HEN alternative 1 that can be made based on the data in Table 2.

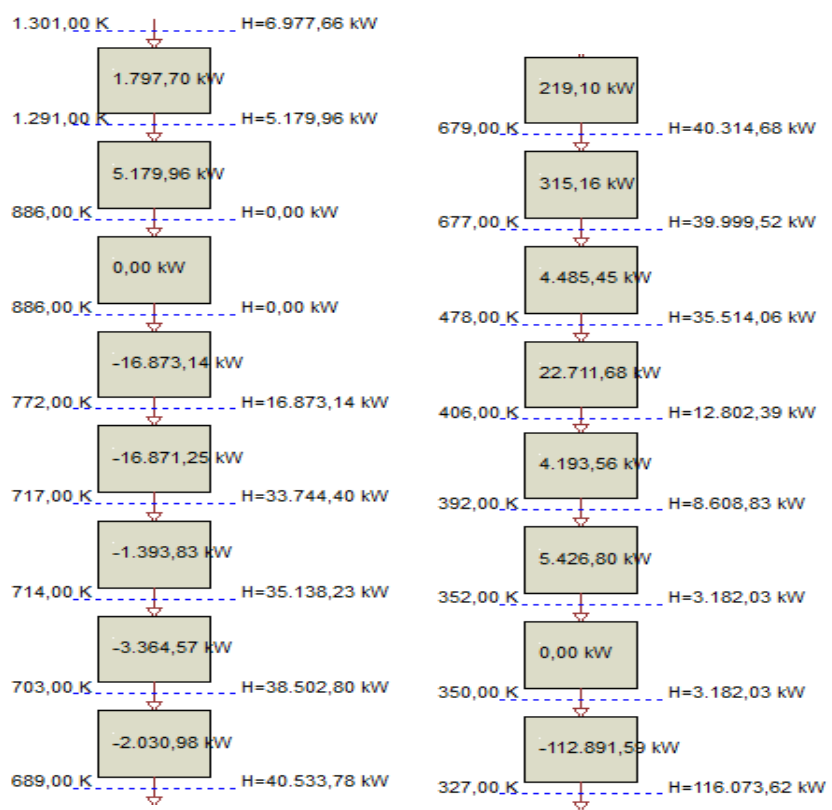

Fig. 5 Cascade diagram of new plant design

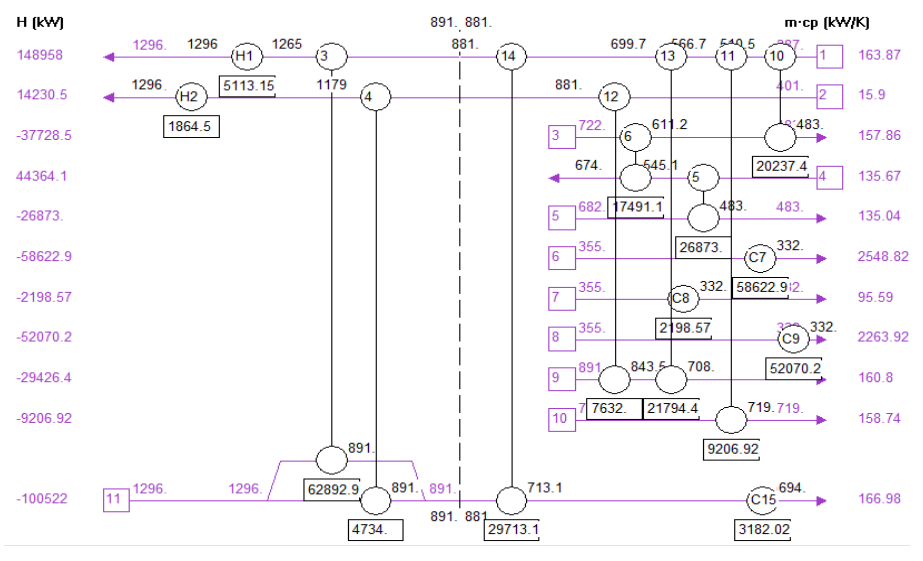

Fig. 6 Alternative design 1 for new plant design

Alternative design 1 is made by splitting stream $11(\mathrm{H} 1)$ at the above pinch. One branch of $\mathrm{H} 1$ is matched with stream 1 (C1) and the other branch is matched with stream 2 (C2). Outputs HE 3 and HE 4 for stream $\mathrm{C} 1$ and stream $\mathrm{C} 2$ are then heated using Heater 1 and Heater 2. While in the below pinch no splitting is done. Matching also conducted between stream $2(\mathrm{C} 2)$ and stream $9(\mathrm{H} 2)$, and the remaining heat from stream 9 $(\mathrm{H} 2)$ is used to heat stream $1(\mathrm{C} 1)$. Then, the heat from stream $3(\mathrm{H} 4)$ and stream 5 (H5) are used to heat stream $4(\mathrm{C} 3)$, and the remaining heat from stream $3(\mathrm{H} 4)$ is used to heat stream $1(\mathrm{C} 1)$. Furthermore, the heat from stream $10(\mathrm{H} 3)$ and stream $11(\mathrm{H} 1)$ are used to heat stream $1(\mathrm{C} 1)$ until reached pinch temperature. Finally, heat from streams 6, 7, 8, and 11 (H6, $\mathrm{H} 7, \mathrm{H} 8$, and $\mathrm{H} 1$ ) that is not used are cooled using a cooling utility.

Alternative design 1 requires 9 heat exchangers for matching hot and cold streams, 2 heaters, and 4 coolers to achieve maximum energy recovery. Alternative design 1 is capable of producing energy recovery of 9,455,670 MW/year with heating and cooling duties of 328,946 MW/year and 5,472,045 MW/year, respectively. The overall flowsheet for alternative design 1 shown in Fig. 7.

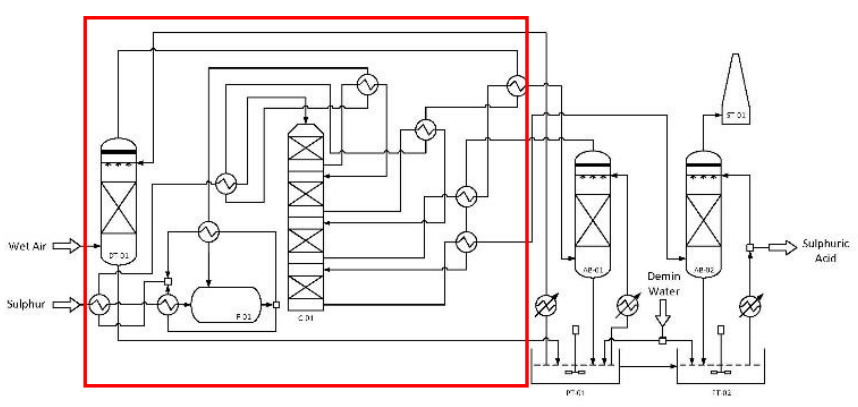

Fig. 7 Alternative design 1 for new plant design

\subsection{Alternative Design 2}

In alternative design 2, heat exchanger networks (HEN) are also carried out through hot and cold streams matching to obtain energy recovery as much as possible. In the above pinch, the matching is done through splitting steam $11(\mathrm{H} 1)$, then the heat is used to heat stream 1 (C1) and stream 2 (C2). The lack of heat in $\mathrm{C} 1$ and $\mathrm{C} 2$ is sufficient by using a heating utility. In the below pinch, heat from streams 3,5 , and 11 ( $\mathrm{H} 4, \mathrm{H} 5$, and $\mathrm{H} 1)$ are used to heat stream 1 (C1) too reached pinch temperature. The remaining heat from stream $3(\mathrm{H} 4)$ is used to heat stream $4(\mathrm{C} 3)$. Then, the heat from stream $9(\mathrm{H} 2)$ and stream $10(\mathrm{H} 3)$ are used to provide enough heat in stream 4 (C3). The remaining heat from stream $9(\mathrm{H} 2)$ is used to heat stream $2(\mathrm{C} 2)$ too reached pinch temperature. Finally, heat from streams 6-9 (H6-H8 and H2) that are not utilized are taken using a cooling utility (see Fig. 8).

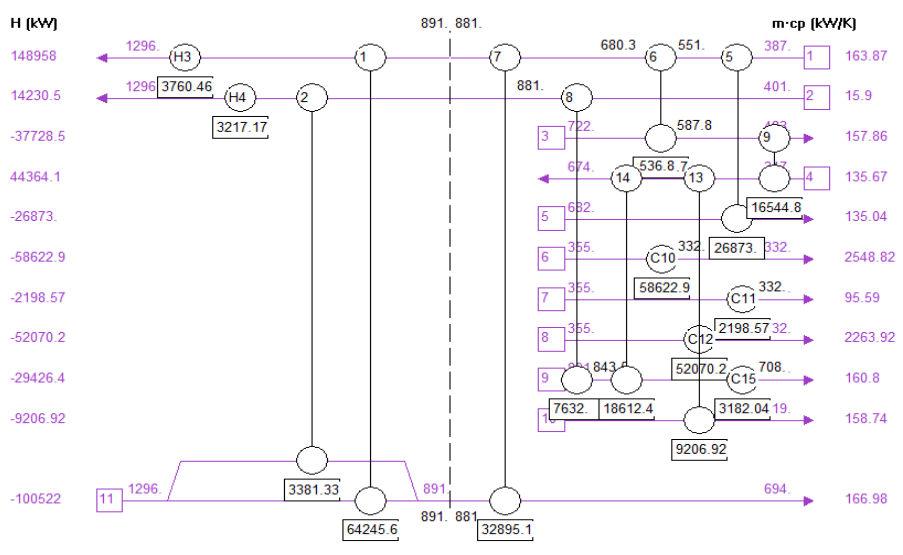

Fig. 8 Alternative design 2 for new plant design

Alternative design 2 also requires 9 heat exchangers for matching hot and cold streams, 2 heaters, and 4 coolers to made the process can run well. Alternative design 2 is capable of producing energy recovery of 9,455,672 MW/year with heating and cooling duties of 328,945 MW/year and 5,472,046 MW/year, respectively. The overall flowsheet for alternative design 2 shown in Fig. 9.

\subsection{Energy Saving and Percent Energy Recovery}

From the overall pinch analysis using the help of HINT software, it can be calculated Maximum Energy Recovery (MER). MER is the amount or the maximum energy load for heating or cooling that can be reduced after integration with pinch analysis (Piacentino, 2011). MER 
value is the difference from the heating or cooling load before and after integration. The results of the energy analysis including MER, percent energy recovery for heating and cooling, and energy saving are shown in Table 3.

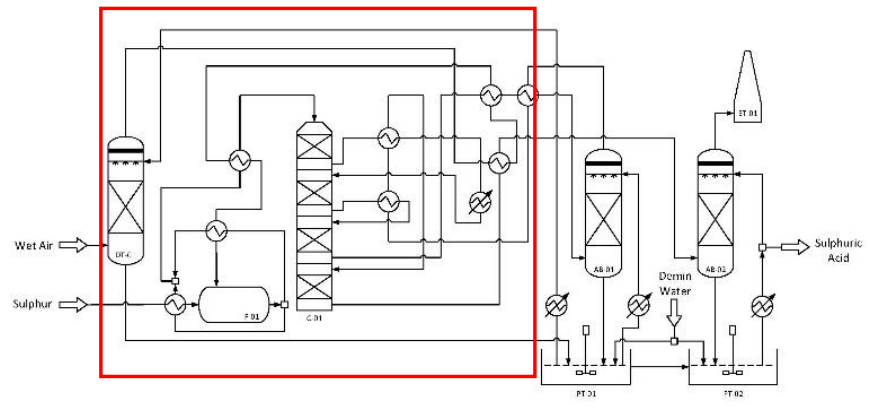

Fig. 9 Flowsheet of alternative design 2

Table 3 Energy saving and recovery for each design.

\begin{tabular}{|c|c|c|c|}
\hline & $\begin{array}{c}\text { Existing } \\
\text { Design }\end{array}$ & $\begin{array}{c}\text { Alternative } \\
\text { Design 1 }\end{array}$ & $\begin{array}{c}\text { Alternative } \\
\text { Design 2 }\end{array}$ \\
\hline $\begin{array}{c}\text { Initial heating duty } \\
\text { (MW/year) }\end{array}$ & 13742932,7 & 9784747,1 & 9784747,1 \\
\hline $\begin{array}{c}\text { Initial cooling duty } \\
\text { (MW/year) }\end{array}$ & 13144911,9 & 13144911,9 & 13144911,9 \\
\hline $\begin{array}{c}\text { Final heating duty } \\
\text { (MW/year) }\end{array}$ & 7693172,1 & 328946,4 & 328945,4 \\
\hline $\begin{array}{c}\text { Final cooling duty } \\
\text { (MW/year) }\end{array}$ & 12836266,5 & 5472045,4 & 5472046,3 \\
\hline MER (MW/year) & 3179203,0 & 8564333,6 & 8564333,6 \\
\hline $\begin{array}{c}\text { Energy recovery for } \\
\text { heating (\%) }\end{array}$ & 44,02 & 96,64 & 96,64 \\
\hline $\begin{array}{c}\text { Energy recovery for } \\
\text { cooling (\%) }\end{array}$ & 2,35 & 58,37 & 58,37 \\
\hline Energy saving (\%) & 23,65 & 74,70 & 74,70 \\
\hline
\end{tabular}

\subsection{Economic Analysis of HEN Design}

Based on the above analysis, the potential for energy savings calculated from alternative design 1 and alternative design 2 are 9,455,670 MW/year and 9,455,672 MW/year, respectively. In this case study, it is clear that the energy saving potential of the two designs is quite close to one another. Therefore, an overall economic cost must be carried out to determine the design to be chosen.

Overall costs can be calculated using the equation:

$T A C=A C C+A O C$

\section{Annual capital cost (ACC)}

To calculate the annual capital cost, it is necessary to first calculate the heat transfer area used for each design. Heat transfer area is calculated by the equation (2) (Sojitra, 2016) and total heat transfer area calculated is shown in Table 4. Using equation (3) (Xiao \& Cui, 2017), the estimated annual costs of the heat exchangers (ACHE) needed can be calculated. Using the module factor 3.29 (installation cost, piping, etc.), the total cost of the installed heat exchanger which is then referred to as the annual capital cost (ACC) can be calculated using equation (4) (Rashid et al., 2011).

$A=\frac{Q}{U x \Delta T_{L M T D}}$

$A C H E(\$ /$ year $)=8000+500 A^{0.75}\left(\right.$ A in $\left.^{2}\right)$

ACC $(\$ /$ year $)=A C H E(\$ /$ year $) x$ module factor
Table 4 Annual capital cost for each design

\begin{tabular}{|c|c|c|c|}
\hline & $\begin{array}{c}\text { Existing } \\
\text { Design }\end{array}$ & $\begin{array}{c}\text { Alternative } \\
\text { Design 1 }\end{array}$ & $\begin{array}{c}\text { Alternative } \\
\text { Design 2 }\end{array}$ \\
\hline Number of HE & 12 & 15 & 15 \\
\hline $\begin{array}{c}\text { Overall heat transfer } \\
\text { area }\left(\mathrm{m}^{2}\right)\end{array}$ & 34.4966 & 145.0219 & 166.1539 \\
\hline ACHE (\$/year) & $15,117.1$ & $28,895.1$ & $31,139.4$ \\
\hline ACC (\$/year) & $49,735.2$ & $95,065.0$ & $102,448.8$ \\
\hline
\end{tabular}

\section{Annual operating cost (AOC)}

Operational costs are calculated based on the need for heating and cooling utilities. Annual operational costs can be calculated using equation (5) (Sojitra, 2016). Where heating and cooling utility costs are $\$ 250 / \mathrm{kW} /$ year and $\$ 25 / \mathrm{kW} /$ year, respectively (Xiao \& Cui, 2017).

$A O C=Q_{h o t} x C_{U H}+Q_{c o l d} x C_{U C}$

From equations (5) and (1) the total annual cost (TAC) for each design is presented in Table 5 .

Table 5 Summary of AOC and TAC for each design.

\begin{tabular}{|c|c|c|c|}
\hline & $\begin{array}{c}\text { Existing } \\
\text { Design }\end{array}$ & $\begin{array}{c}\text { Alternative } \\
\text { Design 1 }\end{array}$ & $\begin{array}{c}\text { Alternative } \\
\text { Design 2 }\end{array}$ \\
\hline $\begin{array}{c}\text { Heating duty } \\
\text { (MW/year) }\end{array}$ & $7,693,172$ & 328,946 & 328,945 \\
\hline $\begin{array}{c}\text { Cooling duty } \\
\text { (MW/year) }\end{array}$ & $12,836,266$ & $5,472,045$ & $5,472,046$ \\
\hline $\begin{array}{c}\text { Hot utility cost } \\
\text { (\$/kW/year) }\end{array}$ & 250 & 250 & 250 \\
\hline $\begin{array}{c}\text { Cold utility cost } \\
\text { (\$/kW/year) }\end{array}$ & 25 & 25 & 25 \\
\hline AOC (\$/year) & $78,710.7$ & $7,682.3$ & $7,682.3$ \\
\hline TAC (\$/year) & $128,445.9$ & $102,747.3$ & $110,131.1$ \\
\hline
\end{tabular}

\section{CONCLUSIONS AND RECOMMENDATION}

A HEN that is designed based on variations in the value of $\Delta \mathrm{T}_{\min }$ cannot always be used. Even though it produces a higher energy recovery value, a low $\Delta \mathrm{T}_{\min }$ value will require a very complex network design with a large total area. In this case study, a $\Delta \mathrm{T}_{\min }$ value of $10 \mathrm{~K}$ was chosen along with 2 new design alternatives by eliminating feed water as a producer of MP steam. The current HEN as well as two new alternative designs have been evaluated using the pinch technology principle. All designs meet HEN design rules based on pinch technology, no external heating below the pinch, no external cooling above the pinch, and no heat transfer across the pinch.

Based on the results of energy and economic analysis shows that revamping the design of the sulfuric acid plant by replacing feed water as a producer of MP steam and removing it from the cold flow list, can significantly improve energy recovery and reduce total annual cost. Two new alternative designs can increase energy saving to $74.70 \%$ compared to existing design which is only $23.65 \%$. The two proposed new design alternatives have the same amount of energy recovery and energy saving. However, alternative design 1 economically requires lower costs than alternative design 2. Alternative design 1 and 2 are each able to save annual costs of $\$ 25,698.6 /$ year and $\$ 18,314.8 /$ year. Thus, alternative design 1 is considered suitable to be selected as a new process design.

\section{NOMENCLATURE}

$\Delta \mathrm{T}_{\min } \quad$ minimum temperature difference

ACC annual capital cost

AOC annual operating cost 


$\begin{array}{ll}\text { CP } & \text { heat capacity flowrate } \\ \mathrm{C} & \text { cold stream } \\ \mathrm{H} & \text { heat stream } \\ \mathrm{HE} & \text { heat exchanger } \\ \mathrm{HEN} & \text { heat exchanger network } \\ \mathrm{kW} & \text { unit, kilowatt } \\ \text { MER } & \text { maximum energy recovery } \\ \text { MW } & \text { unit, megawatt } \\ \text { MP steam } & \text { medium pressure steam } \\ \text { QCmin } & \text { minimum cold utility } \\ \text { QHinin } & \text { minimum hot utility } \\ \text { TAC } & \text { total annual cost } \\ \text { Ts } & \text { inlet temperature hot and cold stream } \\ \text { Tt } & \text { outlet temperature hot and cold stream } \\ \text { Subscripts } & \\ 1 & \text { liquid phase } \\ \text { aq } & \text { aqueous phase } \\ \text { s } & \text { solid phase } \\ \text { g } & \text { gaseous phase } \\ \infty & \text { ambient environment }\end{array}$

\section{REFERENCES}

Acton, Q.A., 2011, Sulfur Acids: Advances in Research and Application, 2011 Ed., ScholarlyEditions, Atlanta.

Bujang, N., Rodhi, M.N.M., Musa, M., Subari, F., Idris, N., Mahktar, N.S.M., and Hamid, K.H.K., 2013, "Effect of Dilute Sulfuric Acid Hydrolysis of Coconut Dregs on Chemical and Thermal Properties," Procedia Engineering, 68, 372-378.

https://doi.org/10.1016/j.proeng.2013.12.194

Djaeni, M., Bartels, P., Sanders, J., van Straten, and G., J. B. van Boxtel, A., 2010, "Process Integration for Food Drying with Air Dehumidified by Zeolites," Drying Technology, 25(1), 225-239.

http://dx.doi.org/10.1080/07373930601161096

Ferdous, K., Uddin, M.R., Mondal, S.K., and Khan, M.R., 2013, "Preparation of Biodiesel Using Sulfuric Acid as a Catalyst," Proceedings of the International Conference on Engineering Research, Innovation and Education 2013 (ICERIE 2013), 11-13 January, SUST, Sylhet, Bangladesh.

Gominšek, T., Lubej, A., and Pohar, C., 2005, "Continuous Precipitation of Calcium Sulfate Dihydrate From Waste Sulfuric Acid and Lime," Journal of Chemical Technology and Biotechnology, 80, 939-947. https://doi.org/10.1002/jctb.1266

Górecka, H., Górecki, H., Chojnacka, K., Baranska, M., Michalak, I., and Zielinska, A., 2007, "New Role of Sulfuric Acid in Production of Multicomponent Fertilizers from Renewable Sources," American Journal of Agricultural and Biological Sciences, 2(4), 241-247. https://doi.org/10.3844/ajabssp.2007.241.247

Kemmerich, M., and Storch, H., 2016, "Process Heat Recovery and Digitalisation in Sulphuric Acid Plants," Procedia Engineering, 138, 220-230.

https://doi.org/10.1016/j.proeng.2016.02.079

Khalid, M.K., Hamuyuni, J., Agarwal, V., Pihlasalo, J., Haapalainen, M., and Lundström, M., 2019, "Sulfuric Acid Leaching for Capturing Value from Copper Rich Converter Slag," Journal of Cleaner Production, 215, 1005-1013.

https://doi.org/10.1016/j.jclepro.2019.01.083

Kiss, A.A., Bildea, C.S., and Berheijen, P.J.T., 2006, "Optimization Studies in Sulfuric Acid Production," Computer Aided Chemical Engineering, 21, 737-742.

https://doi.org/10.1016/S1570-7946(06)80133-1
Kobayashi, T., Sakai, Y., and Iizuka, K., 1960, "Hydrolysis of Cellulose in a Small Amount of Concentrated Sulfuric Acid," Journal of Agricultural Chemical Society of Japan, 24(5), 443-449.

https://doi.org/10.1271/bbb1924.24.443

Kumar, M., Mayavan, S., Ganesan, M., and Ambalavanan, S., 2015, "Effect of Using Sonicated Sulphuric Acid as an Electrolyte in a Lead Acid Battery," RSC Advances, 5, 76065-76067.

https://doi.org/10.1039/C5RA17286A

Linnhoff, B., and Flower, J.R., 1978, "Synthesis of Heat Exchanger Networks. Part I: Systematic Generation of Energy Optimal Network's, AIChE Journal, 24(4), 633-642.

https://doi.org/10.1002/aic.690240411

M'hamdi, A.I., Kandri, N.I., Zerouale, A., Blumberga, D., and Gusca, J., 2017, "Life Cycle Assessment of Paper Production from Treated Wood," Energy Procedia, 128, 461-468.

https://doi.org/10.1016/j.egypro.2017.09.031

Panossian, Z., Almeida, N.L.D., Sousa, R.M.F.D., Pimenta, G.D.S., and Marques, L.B.S., 2012, "Corrosion of Carbon Steel Pipes and Tanks by Concentrated Sulfuric Acid: A Review," Corrosion Science, 58, 1-11. https://doi.org/10.1016/j.corsci.2012.01.025

Piacentino, A., 2011, "Thermal Analysis and New Insights to Support Decision Making in Retrofit and Relaxation of Heat Exchanger Networks," Applied Thermal Engineering, 31(16), 3479-3499. https://doi.org/10.1016/j.applthermaleng.2011.07.002

Putra, Z.A., 2017, "Improving Heat Exchanger Network Design of a Revamped Chemical Plant," Indonesian Journal of Science \& Technology, 2(1), 87-96. https://doi.org/10.17509/ijost.v2i1.5992

Rashid, S.R., Ibrahim, U.K., and Alauddin, S.M., 2011, "Retrofit Design of Heat Exchanger Network (HEN) on Synthesis and Purification Unit of Methanol Plant," Colloquium on Humanities, Science and Engineering Research (CHUSER), Dec 5-6 2011, Penang, Malaysia. https://doi.org/10.1109/CHUSER.2011.6163746

Shabgard, H., and Faghri, A. 2019. "Exergy Analysis in Energy Systems: Fundamentals and Application," Frontier in Heat and Mass Transfer (FHMT), 12(9), 1-16. https://doi.org/10.5098/hmt.12.9

Sojitra, R., 2016, "Application Algorithm Development of Pinch Technology in Heat Integration Problem," Journal of Chemical Engineering \& Process Technology, 7(5), 1-4.

https://doi.org/10.4172/2157-7048.1000314

Speight, J.G., 2017, "Chapter Two: Inorganic Chemistry," Environmental Inorganic Chemistry for Engineers, 51-110.

https://doi.org/10.1016/B978-0-12-849891-0.00002-3

Tongwen, X., and Weihua, Y., 2001, "Sulfuric Acid Recovery from Titanium White (Pigment) Waste Liquor Using Diffusion Dialysis with A New Series of Anion Exchange Membranes - Static Runs," Journal of Membrane Science, 183, 193-200. https://doi.org/10.1016/S0376-7388(00)00590-1

Wang, G.Q., Xu, Z.C., and Ji, J.B., 2011, "Progress on Higee Distillation-Introduction to a New Device and Its Industrial Applications," Chemical Engineering Research and Design, 89(8), 1434-1442.

https://doi.org/10.1016/j.cherd.2011.02.013

Xiao, Y., and Cui, G., 2017, “A Novel Random Walk Algorithm with Compulsive Evolution for Heat Exchanger Network Synthesis," Applied Thermal Engineering, 115, 1118-1127.

https://doi.org/10.1016/j.applthermaleng.2017.01.051 